\title{
New data on distribution of musk ox Ovibos moschatus in the Late Pleistocene in the south-east of Western Siberia and the Minusinsk Depression
}

\author{
Dmitriy G. Malikov*, Andrey V. Shpansky \& Svetlana V. Svyatko
}

\begin{abstract}
New data on the timing of the maximum distribution and diet of Ovibos moschatus in south Siberia in the Late Pleistocene are presented. The southern border of the range of musk ox in the West Siberian Plain during the Karginian time (Denekamp Interstadial, DEN) was located in the Tomsk Ob' River region. During the maximum cooling of the Sartanian time (LGM), the southern boundary of the range was limited by the Minusinsk Depression and the foothill plain of the Altai Mountains. Musk oxen of Tomsk $\mathrm{Ob}$ ' River region had a normal diet similar to that of Pleistocene musk ox and reindeer, and slightly different from the diet of modern musk ox. The diet of musk ox from the Minusinsk Depression was different from that of both the Pleistocene and modern musk oxen, and it was close to that of horses and woolly rhinos. It is possible that the diet of musk ox from the Minusinsk Depression had higher content of in grass and willow.
\end{abstract}

How to cite this article: Malikov D.G., Shpansky A.V., Svyatko S.V. 2020. New data on distribution of musk ox Ovibos moschatus in the Late Pleistocene in the south-east of Western Siberia and the Minusinsk Depression // Russian J. Theriol. Vol.19. No.2. P.183-192. doi: 10.15298/rusjtheriol.19.2.09.

KEY WORDS: musk ox, Late Pleistocene, Minusinsk Depression, West Siberian Plain, geographical distribution, stable isotope analysis, paleodiet.

Dmitriy G. Malikov [dgmalikov@igm.nsc.ru], Sobolev Institute of Geology and Mineralogy Siberian Branch of the Russian Academy of Sciences, Akademika Koptyuga pr. 3, Novosibirsk630090,Russia; Andrey V.Shpansky [shpansky@, ggf.tsu.ru], Department of Paleontology and Historical Geology, Tomsk State University, Lenin pr. 36, Tomsk 634050, Russia; Svetlana V. Svyatko [s.svyatko@qub.ac.uk], 14CHRONO Centre for Climate, the Environment, and Chronology, School of Geography, Archaeology and Paleoecology, Queen's University Belfast, Belfast, Northern Ireland, UK.

\section{Новые данные о распространении овцебыка Ovibos moschatus на юго-востоке Западной Сибири и в Минусинской котловине в позднем неоплейстоцене}

\author{
Д.Г. Маликов*, А.В. Шпанский, С.В. Святко
}

РЕЗЮМЕ. Приведены новые данные о времени максимального распространения и питании овцебыка Ovibos moschatus на юге Сибири в позднем неоплейстоцене. В каргинское время (интерстадиал Денекамп, DEN) южная граница ареала овцебыка в пределах Западно-Сибирской равнины располагалась в Томском Приобье. В максимальное похолодание сартанского времени (LGM) южная граница ареала ограничивалась Минусинской котловиной и предгорной равниной Алтая. Овцебыки Томского Приобья имели нормальный рацион, схожий с рационом плейстоценовых овцебыков и северных оленей, и немного отличный от рациона современных овцебыков. Диета овцебыка из Минусинской котловины отличалась от рациона как плейстоценовых, так и современных овцебыков и была близка к рациону лошадей и шерстистых носорогов. Возможно, в его рационе было высокое содержание травы и ивы.

КЛЮЧЕВЫЕ СЛОВА: овцебык, поздний неоплейстоцен, Минусинская котловина, Западно-Сибирская равнина, географическое распространение, анализ стабильных изотопов, палеодиета.

\section{Introduction}

Among the animals of the mammoth fauna, musk ox Ovibos moschatus Zimmermann, 1780 is of a particular interest. Along with reindeer and arctic fox, it represents

* Corresponding author the arctic group of species which penetrated deep into south of Western and Central Siberia (Shpansky, 2018). Extralimital records of musk ox are a reliable indicator of harsh climatic conditions with shallow snow cover and low summer temperatures based on ecology of the extant $O$. moschatus as an extremely stenobiont species regarding humidity and temperature (Danilkin, 2005). 
Therefore, fossil records of musk ox are useful for paleoclimatic and paleolandscape reconstructions, assuming similar ecologies throughout the history of the lineage. Isotopic studies of fossils and recent musk oxen indicate that in the Pleistocene ecology of musk ox can be more diverse than at present (Raghavan et al., 2014). For a better understanding of the ecology and history of the species, the study of a larger number of fossil remains from the pre-existing species range is essential.

In this respect the records of musk oxen from southern parts of Siberia with varying taxonomic and chronological identifications are of particular interest. An incomplete skull of the Praeovibos sp. is one of the oldest records of musk ox remains in the West Siberian Plain. It was discovered by Zinova (1972) on the Irtysh River shore upstream from the mouth of the Ishim River and attributed to the Late Eopleistocene (=late Early Pleistocene in modern terminology). A possible older record is the fragment of upper jaw of Ovibovini gen. indet. from the Bachat quarry of the Kuznetsk Basin; it was found in the Mokhovo Formation deposits and dates to the first half of Eopleistocene $=$ Upper Villafranchian (Foronova, 2001; Vislobokova, 2008). For the Lower Pleistocene deposits, Bobkovskaya (2002) mentions the fragments of two skulls of Praeovibos priscus Staudinger, 1908 from the Gornofilino location (the right bank of the Irtysh River, near the Gornopravdinsk Village). Remains of $O$. moschatus were found in deposits of the second half(MIS 2-3) of the Upper Pleistocene (Shpansky, 2018; Stefaniak et al., 2019).

Few papers have been focused on the boundaries of the maximum distribution and dynamics of the musk ox habitat in North Asia in the Late Pleistocene (Gromova, 1935; Kahlke, 2014; Markova et al., 2015). The majority of musk ox remains in this area are located north of $56^{\circ} \mathrm{N}$. Belyaeva (1933) mentions a single bone on the Irtysh River shore below Omsk City (above $55^{\circ} \mathrm{N}$ ). In the Novosibirsk Ob' River area, musk ox remains were recovered from the beach of Chik River location, which is supposedly older than MIS 3 (Lobachev et al., 2011). The most southern record of musk ox in Siberia comes from the Minusinsk Depression (Gromova, 1935).

The majority of musk ox finds in Siberia have no stratigraphic references (Tikhonov, 1994). As such, the stratigraphy and paleoecology interpretation of these materials is difficult. This paper presents new data on time range and ecology of $O$. moschatus in the south-east of West Siberia and the Minusinsk Depression based on ${ }^{14} \mathrm{C}$ dating and stable carbon $\left(\delta^{13} \mathrm{C}\right)$ and nitrogen $\left(\delta^{15} \mathrm{~N}\right)$ isotope analysis.

\section{Materials and methods}

Musk ox fossil remains from the following museums were investigated: Minusinsk Martyanov Museum (Minusinsk, MMM) - MMM 7207/132, found in 1924 near the city of Minusinsk; Tomsk Regional Museum of Local Lore (Tomsk, TRM) — TRM 10300/168. Location: Tom River shore, above the Chernilshchikovo Village $\left(56^{\circ} 36^{\prime} \mathrm{N}, 8^{\circ} 51^{\prime} \mathrm{E}\right), 30 \mathrm{~km}$ north-west from Tomsk, May 1958 (Fig. 1).
Skull measurements (Fig. 2) were taken point to point, using a caliper, with a precision to the nearest $0.1 \mathrm{~mm}$ according to the standard scheme of measurements of the bovine skull (Driesch, 1976), adapted for the Ovibos skull. AMS ${ }^{14} \mathrm{C}$ dating and stable carbon $\left(\delta^{13} \mathrm{C}\right)$ and nitrogen $\left(\delta^{15} \mathrm{~N}\right)$ isotope analysis were carried out in the 14CHRONO Centre for Climate, the Environment, and Chronology (Queen's University Belfast, UK), lab. code - UBA. For comparison, we used stable isotope data for mammals of the similar geological age from Europe (Bocherens et al., 2015; Krajcarz et al., 2016), Western and south of Central Siberia (Iacumin et al., 2000, and our data) and recent musk ox from Greenland (Raghavan et al., 2014). We evaluated our ${ }^{14} \mathrm{C}$ and isotope data in the context of regional climatic stratigraphic horizons (Volkova \& Babushkin, 2000) and climatic records following Markova et al. (2015).

\section{Results}

The nearly complete skull from Minusinsk (MMM $7207 / 132$ ) belonged to an adult animal (Fig. 3). Its frontal sutures are fully obliterated, facial sutures are barely noticeable, and only nasal sutures are clearly visible. Only the premaxillary bones, teeth of the right side and left $\mathrm{P} 2$ are absent.

The skull is low, slightly elongated in the anteriorposterior direction, especially in the facial region. Maxillary bones are remarkably narrowed at the level of infraorbital foramen, with subsequent widening anteriorly. The posterior edge of the nasal bones reaches the level of the anterior orbit and M2. The lacrimal bone has a structure characteristic to O. pallantis $\mathrm{H}$. Smith, 1827 (Tikhonov, 1994) in that it slightly narrows towards the orbit, without abrupt interceptions (Fig. 3). The pit on the lacrimal is shallow. The anterior upper protrusion of the squama temporalis forms a straight suture with the lacrimal bone, and in the posterior third the sutures between these bones are obliterated.

Orbits are round, widely spaced, their edges extend beyond the level of the lateral walls of the horn cores, their walls are thick, thinned in front, orbital wall with a small hole. The horncore bases are elongated in the anterior-posterior direction and are separated by a groove; width between horncore bases is $6 \mathrm{~mm}$. The area approaching the position of the horncore tips is directed medially. Fossa temporalis is short and shallow. The sutura coronalis is not pronounced. The occiput is low, almost rectangular in shape. Occipital bone is slightly narrowed anteriorly, its posterior muscular tubercula are well defined and separated by cutouts on the sides of the mastoid processes. The occipital condyles are widely set apart, their articular surfaces do not merge, and the foramen magnum is narrow. Teeth of the left side (P3M3) are preserved within the skull, with some damage on the buccal side. The masticatory surface is heavily worn, the P3 and M1 enamel loops (basal column) are almost completely worn down. Basal column on M2 and M3 is well expressed. The presence or absence of the basal column on M1 is impossible to determine due to the 


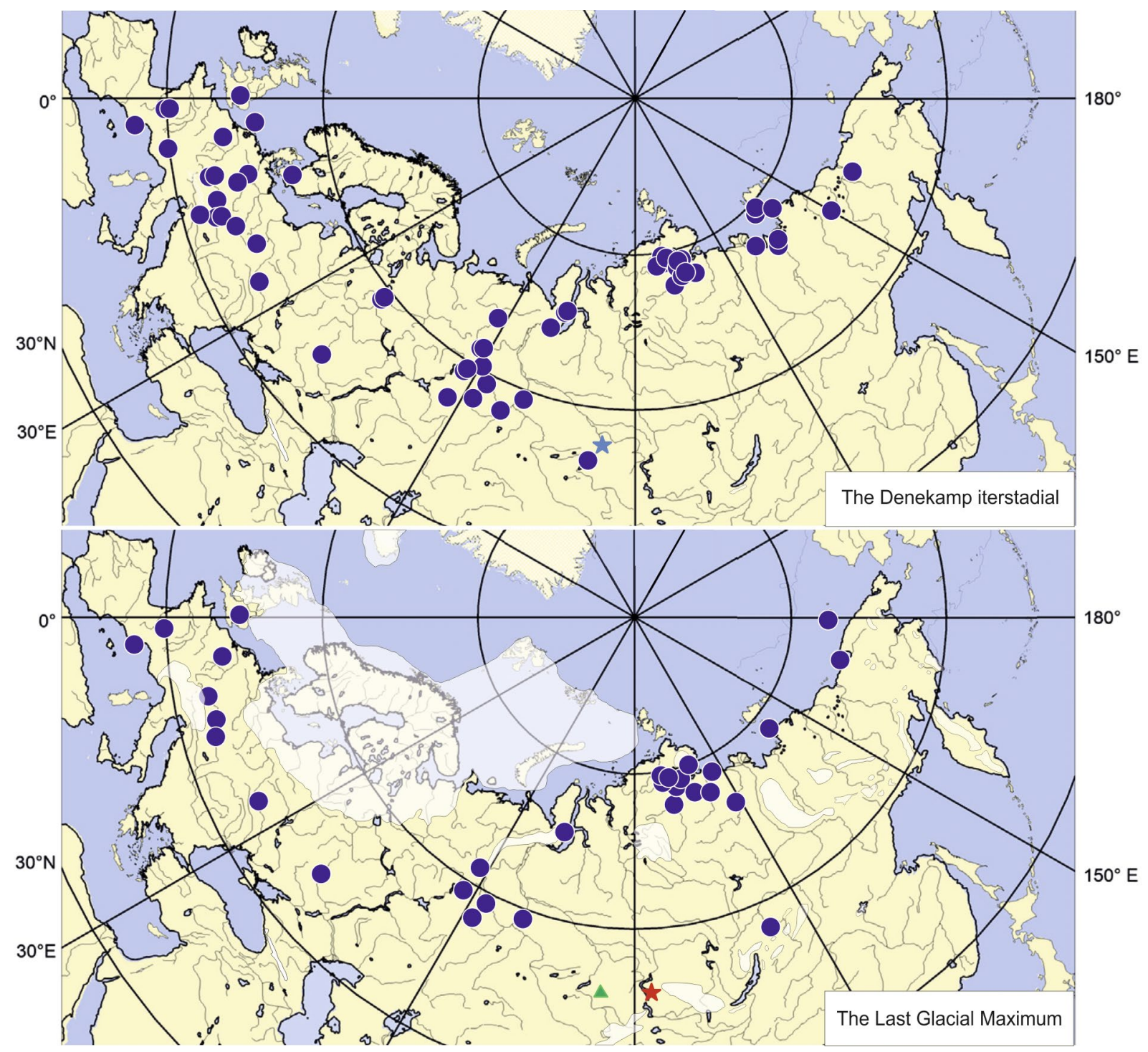

Fig. 1. Geographical distribution of dated musk oxen in Europe and North Asia (adapted from Markova et al., 2015): blue star - Chernilshchikovo, red star — Minusinsk, green triangle — Chumysh River (Vasiliev et al., 2018).

severe tooth wear. The presence of the basal column is a characteristic feature for O. pallantis (Tikhonov, 1994).

In the skull from Chernilshchikovo (TRM 10300/168; Fig. 3) frontal sutures are obliterated, facial sutures are clearly visible, nasal sutures are open and ossa nasale are absent. The facial section bones (praemaxillare and nasale) are broken off; the buccal wall of the left maxillare is damaged; the horncore tips are broken off. Teeth are missing from alveoli. The forehead surface is flat. The orbit walls are thick and round. On the front wall of the orbit there is a fossa, on the frontal surface side there is a well-developed tuberculum. Fossa temporalis is oval. The horncore base is saddle-shaped, wide, square, bent as if embracing the neurocranium, going down vertically below the zygomatic bone. The outer horncore surface is rough, uneven. Occipital foramen is round.
The size of the skull from the Minusinsk specimen is rather small; in most parameters it is exceeded by the animals from Siberia and the European Plain (Tab. 1). At the same time, the length of dentition of the individual from the Minusinsk Depression is slightly larger than that of samples from Siberia and Eastern Europe (Tab. 1). This is especially obvious from premolars. The skull from Chernilshchikovo is the largest among the known Eurasian musk oxen (Tab. 1); the horncores, orbital width, width between the buccal walls of the teeth and the occiput are especially massive.

The morphological structure of the studied musk ox skulls corresponds to the $O$. pallantis species. However, analysis of both ancient and modern musk ox DNA revealed the genetic homogeneity of fossils and modern forms (Campos et al., 2010). Therefore, we classify our materials as $O$. moschatus. 

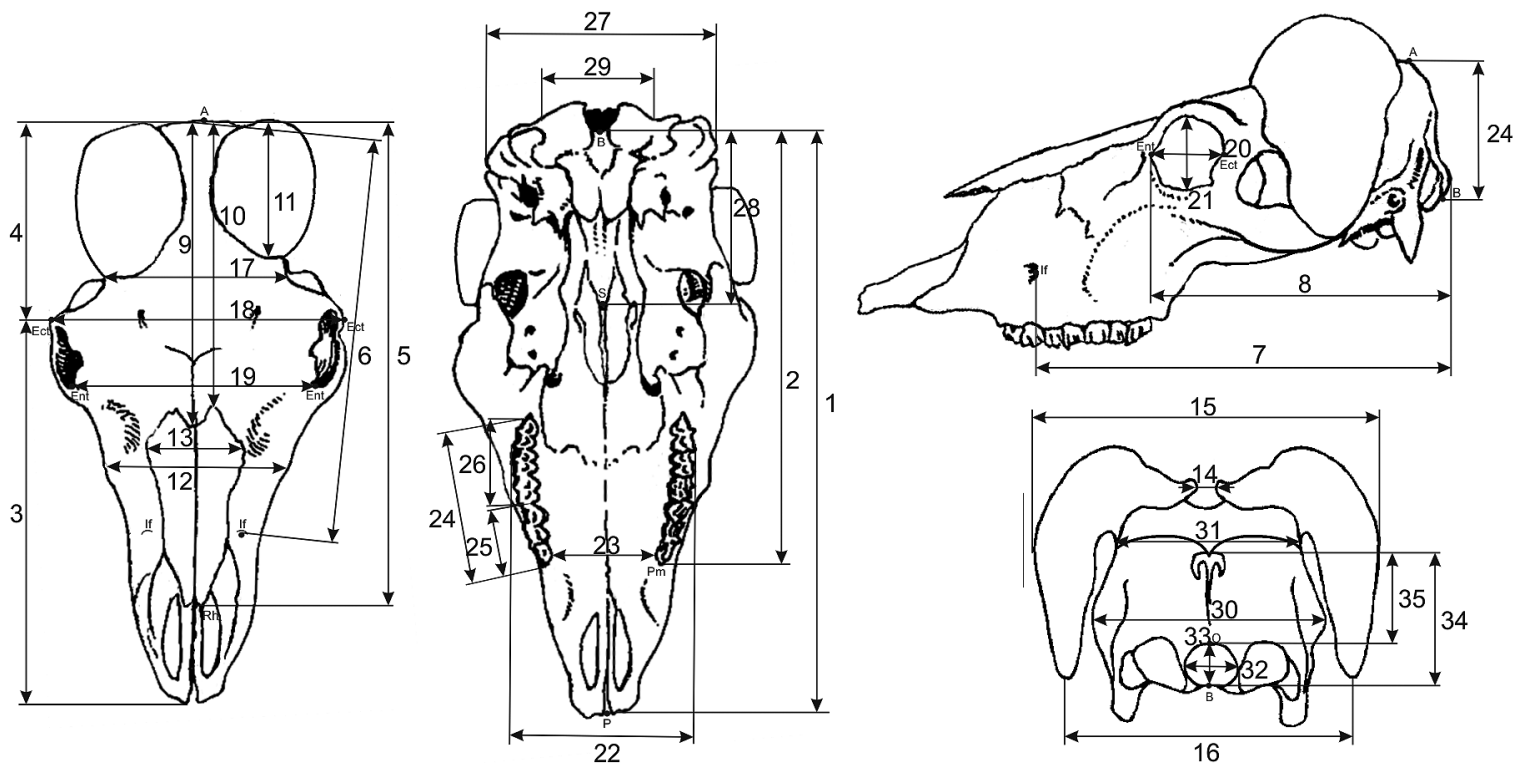

Fig. 2. Scheme of skull measurements in Ovibos moschatus (modified after Danilkin, 2005, measurements adapted from Driesch, 1976): 1 — basal length (basion — prosthion); 2 - short skull length (basion — premolare); 3 — facial length (ectorbitale prosthion); 4 - cranial length (akrocranial — ectorbitale); 5 - short upper cranial length (akrocranial — rhinion); 6 - length from akrocranial to infraorbitale of one side; 7 — length from occipital condyles to infraorbitale of the same side; 8 - length from basion to entorbitale of the same side; 9 - median frontal length (akrocranial - nasion); 10 - small frontal length (from akrocranial to median point of intersection of the line joining the oral points of the frontals); 11 — greatest (oro-aboral) diameter of the horncore base; 12 - facial breadth (across the facial tuberosities); 13 - greatest breadth across the nasal; 14 - least breadth between the bases of the horncores; 15 - greatest tangential distance between the outer curves of the horncores; 16 least distance between the horncore tips; 17 - least frontal breadth (breadth of the narrowest part of the frontal aboard of the orbits); 18 - greatest frontal breadth (between ectorbitale); 19 - least orbital breadth (between entorbitale); 20 — greatest inner length of the orbit (ectorbitale - entorbitale); 21 - greatest inner height of the orbit (perpendicular to m.20); 22 - greatest palatal breadth - across the outer borders of the alveoli; 23 - least palatal breadth - across the inner borders of P2 alveoli; 24 - upper cheek teeth row length P2-M3; 25 - upper premolars row length on alveoli P2-P4; 26 - upper molars row length on alveoles M1-M3; 27 — greatest mastoid breadth (between otion); 28 — basicranial axis (basion — synsphenion); 29 — greatest breadth of occipital condyles; 30 - greatest breadth at the bases of the paraoccipital processes; 31 - smallest width of occiput; 32 greatest breadth of the foramen magnum; 33 — height of the foramen magnum (basion — opisthion); 34 — greatest height of occiput (akrocranion — basion); 35 — least height of occiput (akrocranion — opisthion).

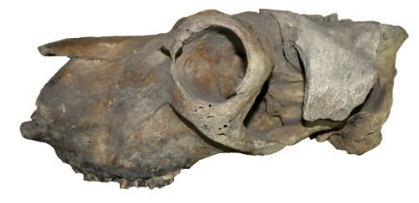

A

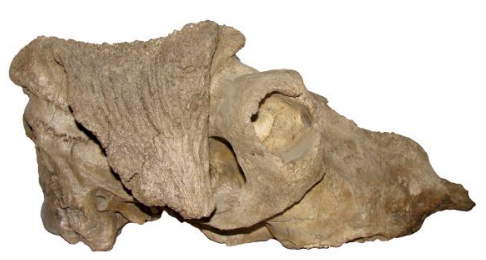

D
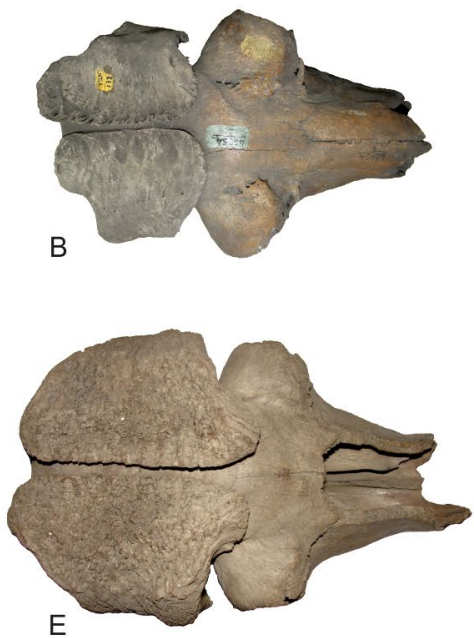

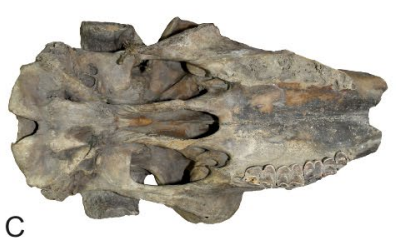

$10 \mathrm{~cm}$

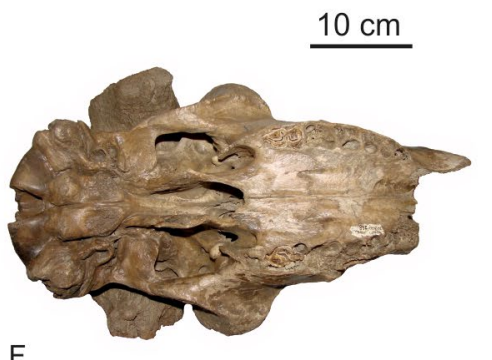

Fig. 3. Ovibos moschatus skulls: Minusinsk skull (MMM 7207/132) — A, B, C; Chernilshchikovo skull (TRM 10300/168) — E, F, D. The lateral (A, E), dorsal (B, F) and basal (C, D) views. 
Table 1. The measurements (mm) for the fossil Ovibos skulls from Northern Eurasia.

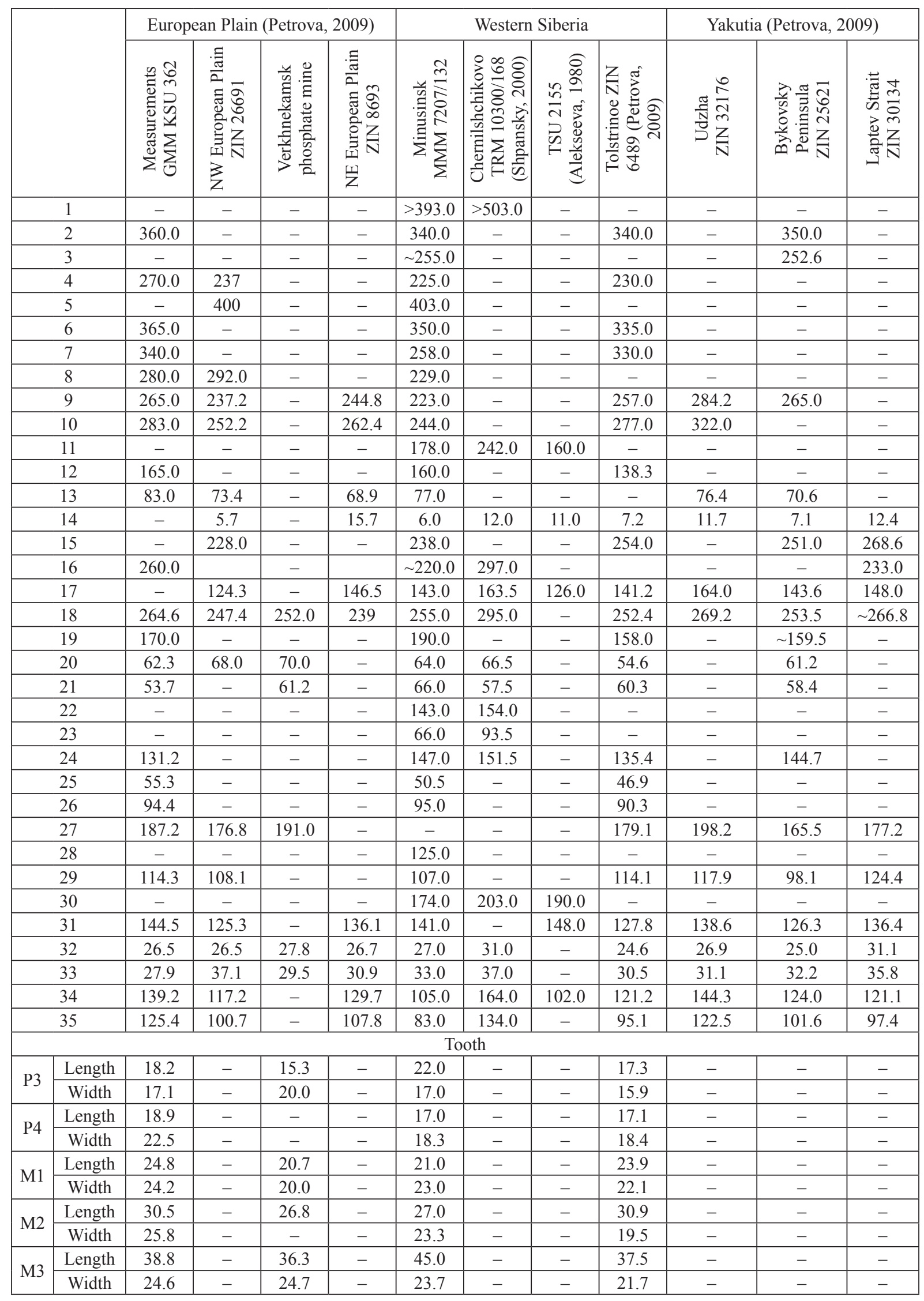


The skull from the Minusinsk Depression does not have exact geographic and stratigraphic provenance (Malikov, 2015). The Pleistocene mammal bone remains found in the Minusinsk Depression are usually light gray and gray-yellow, but the musk ox skull is brown. Based on other remains with similar preservation found with bones of Mammuthus primigenius Blumenbach, 1799 in the Malaya Minusa Village (Minusinsk District, Krasnoyarsk Region), we assume that the studied musk ox skull maybe was found near the same village, in sediments of the Minusinka River $\left(\sim 53^{\circ} 43^{\prime} \mathrm{N}, 91^{\circ} 47^{\prime} \mathrm{E}\right)$.

The obtained radiocarbon $\left({ }^{14} \mathrm{C}\right)$ date for this skull (Tab. 2) corresponds to the maximum cooling of the last glaciation (LGM). The date of the Chernilshchikovo skull indicates that this animal lived during the Karginian interstadial (DEN).

\section{Stable isotope analysis}

The stable nitrogen and carbon isotope analysis of the skulls revealed interesting results. The isotopic composition of the skull from Chernilshchikovo (Fig. 4) is close to that of the reindeer Rangifer tarandus L., 1758 and musk ox O. moschatus remains from Europe (Bocherens et al., 2015; Krajcarz et al., 2016). A similar type of subsistence and selectivity of fodder are characteristic to both species. Thus, isotopic data suggests the presence of normal conditions for the Chernilshchikovo musk ox. Stable isotope data for some large mammals from the south of Western Siberia obtained by authors and others (Iacumin et al., 2000; Raghavan et al., 2014; Jürgensen et al., 2017) show high degree of similarity with the isotopic composition of $O$. moschatus, $R$. tarandus, and Saiga tatarica L., 1766 (Tab. 3). The differences have been recorded for Coelodonta antiquitatis Blumenbach, 1799 and M. primigenius with higher variability of the isotopic composition in Western Siberia than in conspecifics in Europe (Fig. 4). This may indicate regional features in the nitrogen and carbon isotopic ratios, or differences in the animal's palaeodiet.

On the contrary, the musk ox from the Minusinsk Depression revealed a deviation from the norm, as its diet was closer to that of horses and woolly rhinos and different from fossil musk oxen (including one from Chernilshchikovo), recent $O$. moschatus and reindeer (Fig. 4). It remains an outlier even when compared with data for the Pleistocene European (Bocherens et al.,

Table 2. AMS ${ }^{14} \mathrm{C}$ dates for remains of Ovibos moschatus.

\begin{tabular}{|c|c|c|c|c|c|c|c|}
\hline Site & Collection No. & Lab. code & ${ }^{14} \mathrm{C}$ age BP & Cal BP 95.4\% & $\delta^{13} \mathrm{C}$ & $\delta^{15} \mathrm{~N}$ & $\mathrm{C}_{\mathrm{N}} \mathrm{N}_{\mathrm{atm}}$ \\
\hline Minusinsk & MMM 7207/132 & UBA-37843 & $20725 \pm 156$ & $25410-24480$ & -20.1 & 4.8 & 3.17 \\
\hline Chernilshchikovo & TRM 10300/168 & UBA-38454 & $29603 \pm 451$ & $34623-32814$ & -19.0 & 3.2 & 3.26 \\
\hline
\end{tabular}

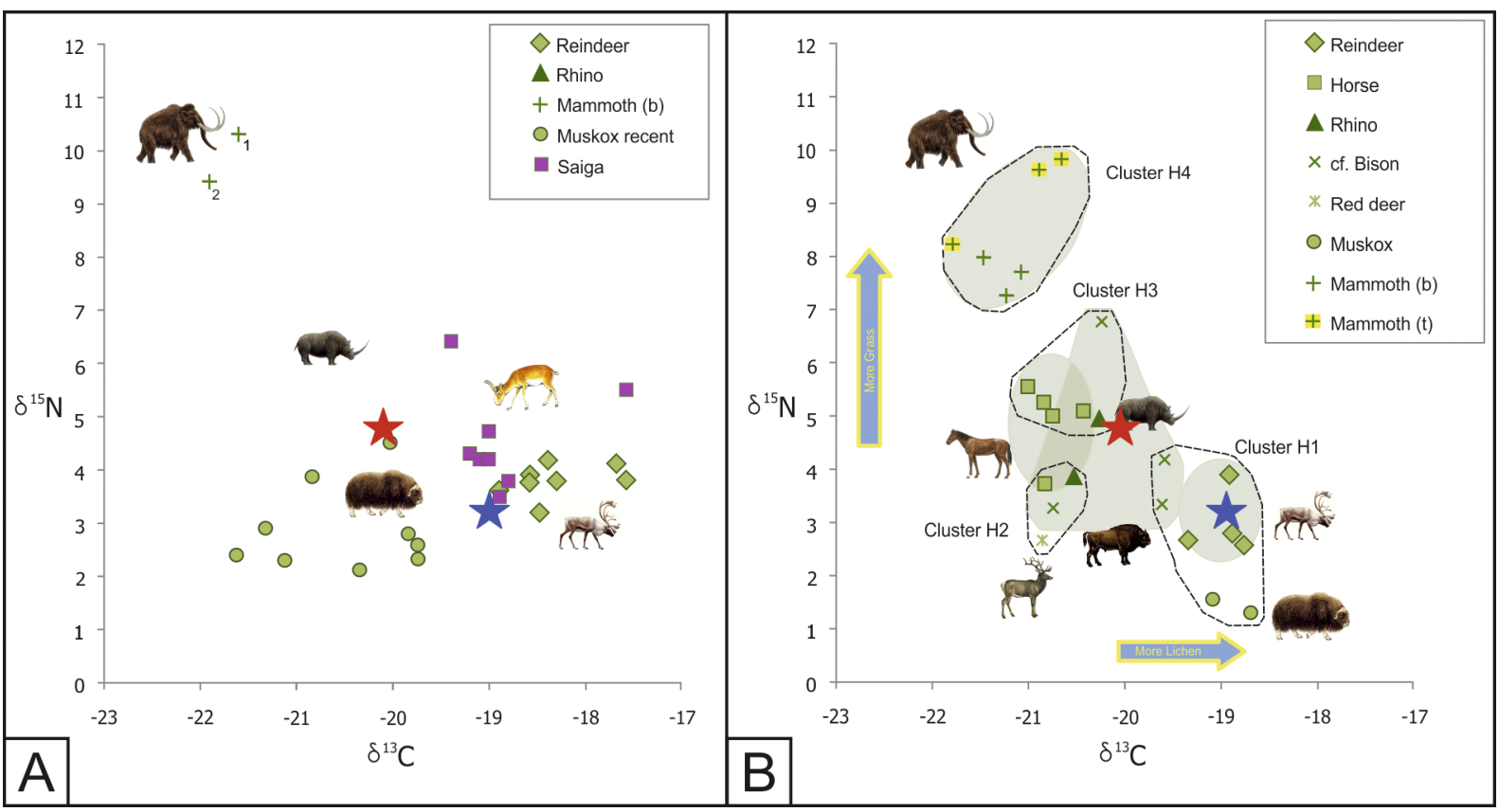

Fig. 4. Ratios of $\delta^{13} \mathrm{C}$ and $\delta^{15} \mathrm{~N}$ of bone collagen of Siberian Ovibos moschatus (Chernilshchikovo — blue star, Minusinsk red star) compared to mammals of Western Siberia, recent musk oxen from Greenland (Raghavan et al., 2014) (A) and Central Eastern Europe (B) (Bocherens et al., 2015). 
Table 3. Results of stable isotope analysis of fossil herbivorous mammals from Siberia.

Museum abbreviations: MMM — Minusinsk Martyanov Museum, Minusinsk; TRM — Tomsk Regional Museum of Local Lore, Tomsk; TSU - Tomsk State University, Tomsk; PM TSU - Paleontology Museum of the Tomsk State University, Tomsk; GMM KSU - Geological and Mineralogical Museum of Kazan State University, Kazan; ZIN — Zoological Institute, Russian Academy of Sciences, Saint Petersburg; GIN — Geological Institute of the Russian Academy of Sciences, Moscow.

\begin{tabular}{|c|c|c|c|c|c|c|}
\hline Site and collection No. & Lab. code & $\%$ coll & $\delta^{13} \mathrm{C}$ & $\delta^{15} \mathrm{~N}$ & $\mathrm{C}: \mathrm{N}_{\mathrm{at}}$ & Reference \\
\hline \multicolumn{7}{|c|}{ Ovibos moschatus } \\
\hline Minusinsk (Minusinsk depr.) - MMM 7207/132 & UBA-37843 & 8.7 & -20.1 & 4.8 & 3.17 & this paper \\
\hline Chernilshchikovo (Tomsk reg.) - TRM 10300/168 & UBA-38454 & 4.6 & -19.0 & 3.2 & 3.26 & this paper \\
\hline \multicolumn{7}{|c|}{ Coelodonta antiquitatis } \\
\hline Sergeevo (Tomsk reg.) — PM TSU 18/1 & UBA-38452 & 9.3 & -20.6 & 7.2 & 3.18 & this paper \\
\hline Krasnoturansk (Minusinsk depr.) — MMM 9437/5 & UBA-39179 & 5.2 & -20.2 & 5.6 & 3.15 & this paper \\
\hline \multicolumn{7}{|c|}{ Mammuthus primigenius } \\
\hline \multirow{2}{*}{ Asino (Tomsk reg.) — TRM 10300/3 } & UBA-38453 & 7.7 & -21.6 & 10.3 & 3.25 & this paper \\
\hline & UBA-39395 & 11.8 & -21.9 & 9.4 & 3.08 & this paper \\
\hline \multicolumn{7}{|c|}{ Saiga tatarica } \\
\hline Aydorakh (Minusinsk depr.) — ZIN 15097 & OxA-22638 & & -19.0 & 4.2 & 3.4 & Jürgensen et al., 2017 \\
\hline Askiz (Minusinsk depr.) - GIN-661 & OxA-22671 & & -19.4 & 6.4 & 3.3 & Jürgensen et al., 2017 \\
\hline Ushaika river (Tomsk reg.) - ZIN 32727 & OxA-22641 & & -19.1 & 4.2 & 3.4 & Jürgensen et al., 2017 \\
\hline Krasniy Yar (Tomsk reg.) - ZIN 32728/1 & OxA-22520 & & -19.2 & 4.3 & 3.4 & Jürgensen et al., 2017 \\
\hline Krasniy Yar (Tomsk reg.) - ZIN 32728/2 & OxA-22612 & & -18.8 & 3.8 & 3.3 & Jürgensen et al., 2017 \\
\hline Kutznetsk depression - ZIN 32725/1 & OxA-22613 & & -19.0 & 4.7 & 3.4 & Jürgensen et al., 2017 \\
\hline Kutznetsk depression - ZIN 32725/2 & OxA-22614 & & -17.6 & 5.5 & 3.3 & Jürgensen et al., 2017 \\
\hline Kutznetsk depression - ZIN 32750 & OxA-22615 & & -18.9 & 3.5 & 3.3 & Jürgensen et al., 2017 \\
\hline \multicolumn{7}{|c|}{ Rangifer tarandus } \\
\hline Kashtanka (Minusinsk depr.) & 1 & 15.2 & -18.4 & 4.2 & 3.3 & Iacumin et al., 2000 \\
\hline Kashtanka (Minusinsk depr.) & 2 & 10.9 & -17.7 & 4.1 & 3.2 & Iacumin et al., 2000 \\
\hline Kashtanka (Minusinsk depr.) & 3 & 9.5 & -18.6 & 3.8 & 3.2 & Iacumin et al., 2000 \\
\hline Kashtanka (Minusinsk depr.) & 4 & 12.3 & -18.5 & 3.2 & 3.2 & Iacumin et al., 2000 \\
\hline Kashtanka (Minusinsk depr.) & 5 & 14.2 & -18.6 & 3.9 & 3.5 & Iacumin et al., 2000 \\
\hline Kashtanka (Minusinsk depr.) & 6 & 12.8 & -17.6 & 3.8 & 3.5 & Iacumin et al., 2000 \\
\hline Kashtanka (Minusinsk depr.) & 7 & 11.7 & -18.9 & 3.6 & 3.4 & Iacumin et al., 2000 \\
\hline
\end{tabular}

2015; Krajcarz et al., 2016) and Siberian (Iacumin et al., 2000; Jürgensen et al., 2017) faunal representatives, and recent musk oxen (Raghavan et al., 2014). The presence of a dietary outlier may suggest a different habitat for the musk oxen from Minusinsk, relative to musk oxen from Tomsk Ob' River and Europe. Further testing of additional specimens will be needed to clarify whether this is an individual anomaly or a regional trend.

\section{Discussion}

Apart from Chernilshchikovo, within the West Siberian Plain, O. moschatus remains from the later part of Late Pleistocene (11.7-57 ka cal. BP) are also known in the multi-species sites of Sergeevo, Krasniy Yar in Krivosheino district (Tomsk Region), Yurovsk (Khanty-Mansi Autonomous Area), Evalga (east of the Sverdlovsk Region), yet no remains have been found to the south of $56^{\circ} \mathrm{N}$ (Shpansky, 2018). Many localities containing the Pleistocene fauna remains are known within the Minusinsk Depression (e.g. Ovodov, 2009). However, after more than a hundred year history of study, only a single record of musk ox is known in this area (Gromova, 1935; Malikov, 2015) This may indicate that the region was not a permanent habitat for the species. We suggest that in the later Late Pleistocene, musk ox dispersed into the Minusinsk Depression only during the LGM, when climatic conditions were most optimal for this species. Given this hypothesis, we anticipate further discoveries of musk ox records in the region, from localities of the similar age (Kurtak 4, Kashtanka, Shlenka, Derbina-4, Novoselovo alluvial, and Pervomayskoe; see Graf, 2009; Motuzko et al., 2010, Malikov \& Ovchinnikov, 2019). Unfortunately, most of these locations are presently submerged by the Krasnoyarsk Reservoir. Therefore, new sites are needed to test the presence of $O$. moschatus in the region during the later part of Late Pleistocene. The fourth cervical vertebra of musk ox was found on the beach of the Chumysh River near the Titovo Village in the Pre-Altai Plain $\left(53^{\circ} 24^{\prime} \mathrm{N}\right)$. 
The date of $16989 \pm 183$ BP (BINP-NSU-1295) obtained at the experimental accelerator mass spectrometer of the Budker Institute of Nuclear Physics SB RAS in Novosibirsk (Vasiliev et al., 2018) suggests the Sartanian age of this fossil. This record (Fig. 1) suggests that the range of O. moschatus had a maximal southward expansion during the LGM. The records from Minusinsk and Chumysh are good indicators that the southernmost expansion of the range of musk ox in the LGM reached the latitude of $53^{\circ} \mathrm{N}$. Increase in humidity and, as a result, depth of snow cover in the foothills of the Eastern Sayan and Altai Mountains possibly became a limiting factor for the further distribution of the species to the south. Modern musk oxen avoid rugged terrains, and do not live in areas with the snow depth exceeding $20-30 \mathrm{~cm}$, with $40-50 \mathrm{~cm}$ at maximum (Danilkin, 2005). This is associated with the specific anatomical features of this animal with short legs, low height of the chest, and a considerable body mass. Landscape features, namely the predominance of low-hill and low-mountain relief mixed with plains and peneplains in the foothill regions, could be another factor limiting musk ox distribution in Southern Siberia (Mistryukov, 1991). The same factors limited the expansion of $S$. tatarica in the Minusinsk Depression (Malikov, 2018).

\section{Paleoecology of musk ox}

The nitrogen and carbon isotope ratios are highly dependent on the ecosystem. The $\delta^{15} \mathrm{~N}$ values of herbivore tissues from arid regions are higher than those in humid regions. As such, an increase in $\delta^{15} \mathrm{~N}$ in bone collagen can interpreted as an indication of drier conditions and a diet based on grassy vegetation (Bocherens et al., 2015). The lower $\delta^{13} \mathrm{C}$ may indicate an increase in the amount of precipitation, or feeding on plants subjected to the "canopy effect" (Kohn, 2010; van der Merwe \& Medina, 1991). For example, modern wet cereals have an average $\delta^{13} \mathrm{C}$ of $29.1 \%$, while in dry habitats they average around $26.9 \%$ in $\delta^{13} \mathrm{C}$ (Wooller et al., 2007); therefore, herbivores that feed on the latter will exhibit higher $\delta^{13} \mathrm{C}$ values.

As it has been mentioned, the carbon and nitrogen isotope ratios in the Chernilshchikovo musk ox are close to those of Pleistocene musk oxen and reindeer from Europe and Siberia, and is slightly different from modern oxen in Greenland. The $\delta^{13} \mathrm{C}$ of Chernilshchikovo musk ox and reindeer from the Minusinsk Depression are within the interval between $-19.0 \%$ and $-17.6 \%$, and their $\delta^{15} \mathrm{~N}$ are between 3.2\%o and 4.2\%o (Fig. 4). In modern Greenland musk oxen, $\delta^{13} \mathrm{C}$ vary between $-21.7 \%$ and $-19.8 \%$, and $\delta^{15} \mathrm{~N}$ between $2.1 \%$ and $2.9 \%$, which implies their habitation in more humid conditions than those of the Pleistocene musk oxen in Siberia. Only two modern specimens have the similar high $\delta^{15} \mathrm{~N}$ ratios $-3.9 \%$ and $4.6 \%$ (Raghavan et al., 2014). The higher $\delta^{13} \mathrm{C}$ values of this group as compared to modern Greenland oxen suggest their habitation in more arid conditions than those of modern Greenland. Another possible reason for the higher $\delta^{13} \mathrm{C}$ in the Pleistocene musk ox is the higher lichen content in its diet, similar to the diet of reindeer (Bocherens et al., 2015), as compared to modern animals.

Unlike the Chernilshchikovo musk ox, the Minusinsk specimen differs both from Pleistocene animals of Siberia and modern Greenland musk oxen (Fig. 4). In most modern musk oxen $\delta^{15} \mathrm{~N}$ ratios are half as high as those in the Minusinsk musk ox. Only one modern specimen from Greenland has carbon and nitrogen isotopic levels $(-20.1 \%$ and $4.6 \%$ ) similar to those of the Minusinsk musk ox (-20.1\%o and 4.8\%o). By $\delta^{13} \mathrm{C}$ and $\delta^{15} \mathrm{~N}$ ratios, the specimen from Minusinsk is closest to woolly rhino and horse (Fig. 4).

As the animals living in arid environments are characterized by increased both $\delta^{13} \mathrm{C}$ and $\delta^{15} \mathrm{~N}$, and the Minusinsk individual is elevated only in $\delta^{15} \mathrm{~N}$ (its $\delta^{13} \mathrm{C}$ are similar to modern animals), it is possible that this is not related to different living conditions.

Perhaps Salix sp., characterized by relatively high $\delta^{15} \mathrm{~N}$ (Michelsen et al., 1998) and low $\delta^{13} \mathrm{C}$ values due to the «canopy effect», were a significant part of the Minusinsk musk ox diet. This is in good agreement with the selectivity of modern musk oxen regarding Salix sp. (Kazmin et al., 2011). Few palynologically characterized Pleistocene sections in the region are generally poor in the pollen of willow. In the Karginian (MIS 3 ) and Sartanian (MIS 2) deposits of the Kurtak archaeological region (160 km north from Minusinsk) pollen of Salix sp. has been observed only occasionally and in small quantities (Drozdov et al., 2005). Thus, the available palynological data is not yet sufficient to consider willow as a widespread fodder in the region in the Late Pleistocene. However, this species was actually found in the region during the period of $O$. moschatus existence, suggesting its possible contribution to the ox diet.

Particularly interesting is the isotopic difference between the Minusinsk specimen and reindeer from the Kashtanka site, also located in the Minusinsk Depression (Tab. 3). The majority of the remains from Kashtanka date to the early Sartanian time, 24400-20800 BP (Lisitsyn, 1997; Drozdov et al., 2005), making this data the most appropriate for the comparative analysis. Even more surprising is the isotopic difference between the musk ox and reindeer that lived in the same region at approximately the same time. Although our sample size from Minusinsk is small, we hypothesize that the diet of reindeer included more lichen, which resulted in an increase in $\delta^{13} \mathrm{C}$ and decrease in $\delta^{15} \mathrm{~N}$ values in their bones. At the moment, this is only a hypothesis that requires additional materials and results of stable isotope analysis. Pollen spectra obtained from the Kashtanka site indicate humid conditions with large shares of forest and tundra vegetation (Drozdov et al., 2005). Further isotopic data for various local species will be essential for a more detailed interpretation of the diet of fossil mammals in the region.

\section{Conclusions}

We studied musk ox skulls from close geographical areas of the Minusinsk Depression and Tomsk Ob' Riv- 
er region dating to the Sartanian and Karginian period respectively. Our data are consistent with the earlier hypothesis (Markova et al., 2015) that during the maximum cooling interval of LGM, O. moschatus in Eurasia reached maximal distribution. The southern boundary of the musk ox range in North Asia was limited to $53^{\circ} \mathrm{N}$. Maximum penetration of the species to the south, to the Minusinsk Depression and Pre-Altai Plain, is recorded for the Sartanian time. This is concurrent with the maximum development of cryo-arid landscapes in the northern half of Western and Middle Siberia (Velichko et al., 2007). The southern border of the musk ox habitat within the West Siberian Plain during the Karginian time (DEN) was located significantly further to north, at $55-56^{\circ} \mathrm{N}$, in the Omsk Irtysh River and Tomsk Ob' River regions.

Stable isotope analysis indicates that musk ox diet in the Tomsk Ob' River region was similar to that of Pleistocene reindeer and musk oxen. Our data suggest that during the Karginian time the landscape and climatic conditions in the Tomsk Ob' River region were suitable for musk oxen. Isotopic analysis of the skull from the Minusinsk Depression, on the contrary, suggests a different diet than that of the Tomsk musk ox. The results are similar to isotopic values found for horses and woolly rhinos. In addition, isotopic data may indicate a diet based on willow Salix sp. and grassy vegetation. Lichens were probably absent in the diet of the Minusinsk musk ox. It is possible that the dietary change reflected the transformation of the vast tundra-steppe zone, and its disintegration into the actual tundra zone in the northern and dry steppe in the southern part, or associated with individual dietary preferences of the Minusinsk musk ox on the edge of the species distribution area. The small number of available materials precludes unambiguous answers to these questions. The search for new materials is necessary to address the existing issues.

ACKNOWLEDGMENTS. The authors would like to acknowledge the administration and staff of the Minusinsk Martyanov Museum for the opportunity to work with the material. The ${ }^{14} \mathrm{C}$ dating of the Minusinsk sample was funded by the Russian Foundation for Basic Research project No. 18-35-00118. Work is done according to the State assignment of IGM SB RAS. This study was supported by the Tomsk State University competitiveness improvement program (research grant No. 8.1.48.2018). The authors thank reviewers for valuable comments and corrections.

\section{References}

Alekseeva E.V. 1980. [Pleistocene Mammals from South-East of Western Siberia (Carnivores, Proboscidians, Ungulates)]. Moscow: Nauka. 188 p. [in Russian].

Belyaeva E.I. 1933. [New data on the Quaternary mammals of Western Siberia] // Izvestiya AN SSSR, otdel matematicheskikh i estestvennykh nauk. Vol.8. P.1205-1207 [in Russian].
Bobkovskaya N.E. 2002. [Large mammals of the Pleistocene of the Lower Irtysh] // Pleistotsen i Pleistotsenovye i Golotsenovye Fauny Urala. Ekaterinburg: University. P.56-61 [in Russian].

Bocherens H., Drucker D.G., Germonpre M., Laznickova-Galetova M., Naito Y.I., Wissing C., Bruzek J. \& Oliva M. 2015. Reconstruction of the Gravettian food-web at Predmostí I using multi-isotopic tracking $\left({ }^{13} \mathrm{C},{ }^{15} \mathrm{~N},{ }^{34} \mathrm{~S}\right)$ of bone collagen // Quaternary International. Vol.359-360. P.211-228.

Campos P.F., Willerslev E., Sher A., Orlando L., Axelsson E., Tikhonov A., Aaris-Sorensen K., Greenwood A.D., Kahlke R.D., Kosintsev P., Krakhmalnaya T., Kuznetsova T., Lemey P., MacPhee R., Norris C.A., Shepherd K., Suchard M.A., Zazula G.D., Shapiro B. \& Gilbert M.T.P. 2010. Ancient DNA analyses exclude humans as the driving force behind late Pleistocene musk ox (Ovibos moschatus) population dynamics // Proceedings of the National Academy of Sciences of USA. Vol.107. No.12. P.5675-5680.

Danilkin A.A. 2005. [Hollow-horned Ruminants (Bovidae)]. Moscow: KMK Scientific Press. 550 p. [in Russian].

Driesch A.A., von den. 1976. Guide to the measurement of animal bones from archaeological sites // Peabody Museum of Archaeology and Ethnology Bulletin. No.1. P.1-137.

Drozdov N.I., Chekha V.P. \& Haesaerts P. 2005. [Geomorphology and Quaternary Deposits of Kurtak Geoarchaeological District (North-Minusinsk Depression)]. Krasnoyarsk: Krasnoyarsk State Pedagogical University named after V.P. Astafiev. 112 p. [in Russian].

Foronova I.V. 2001. [Quaternary Mammals of the South-East of Western Siberia (Kuznetsk Basin): Phylogeny, Biostratigraphy, and Paleoecology]. Novosibirsk: Publishing House of Siberian Branch, Russian Academy of Sciences. 243 p. [in Russian].

Graf K.E. 2009. "The good, the bad, and the ugly": evaluating the radiocarbon chronology of the middle and late Upper Paleolithic in the Enisei River valley, south-central Siberia// Journal of Archaeological Science. Vol.36. P.694-707.

Gromova V.I. 1935. [On the distribution of remains of the muskox Ovibos moschatus Zimm. in Eastern Europe and Northern Asia] // Izvestiya AN SSSR, otdel matematicheskikh i estestvennykh nauk. No.1. P.101-114 [in Russian].

Iacumin P., Nikolaev V. \& Ramigni M. 2000. C and N stable isotope measurements on Eurasian fossil mammals, 40000 to 10000 years BP: herbivore physiologies and palaeoenvironmental reconstruction // Paleogeography, Paleoclimatology, Palaeoecology. Vol.163. No.1. P.33-47.

Jürgensen J., Drucker D.G., Stuart A.J., Schneider M., Buuveibaatar B. \& Bocherens H. 2017. Diet and habitat of the saiga antelope during the late Quaternary using stable carbon and nitrogen isotope ratios // Quaternary Science Reviews. Vol.160. P.150-161.

Kahlke R.-D. 2014. The origin of Eurasian mammoth faunas (Mammuthus-Coelodonta Faunal Complex) // Quaternary Science Reviews. Vol.96. P.32-49.

Kazmin V.D., Kholod S.S., Rozenfeld S.B. \& Abaturov B.D. 2011. [The current state of forage resources and feeding of reindeer (Rangifer tarandus) and the musk ox (Ovibos moschatus) in arctic tundra of Wrangel Island] // Zoologicheskii Zhurnal. Vol.90. No.3. P.1055-1063 [in Russian, with English summary]. 
Kohn M.J. 2010. Carbon isotope compositions of terrestrial C3 plants as indicators of (paleo)ecology and (paleo)climate // Proceedings of the National Academy of Sciences of USA. Vol.107. No.46. P.19691-19695.

Krajcarz M., Pacher M., Krajcarz M.T., Laughlan L., Rabeder G., Sabol M., Wojtal P. \& Bocherens H. 2016. Isotopic variability of cave bears $\left(\delta^{15} \mathrm{~N}, \delta^{13} \mathrm{C}\right)$ across Europe during MIS 3 // Quaternary Science Reviews. Vol.131. P.51-72.

Lisitsyn N.F. 1997. [Relative and Absolute Chronology of the Upper Paleolithic in the South of Middle Siberia]. Saint Petersburg: Institute for the History of Material Culture of Russian Academy Science. 119 p. [in Russian].

Lobachev Yu.V., Vasiliev S.K., Zol'nikov I.D. \& Kuzmin Y.V. 2011. [Large location of Pleistocene fauna on Chik River (Novosibirsk region)] // Problems of Archaeology, Ethnography, Anthropology of Siberia and Neighboring Territories. Vol.17. P.72-77 [in Russian].

Malikov D.G. 2015. [Large Mammals of the Middle-Late Neopleistocene of the Minusinsk Depression, Stratigraphic Value and Paleozoogeography] // [PhD Dissertation in Geology]. Tomsk: Tomsk State University. 227 p. [in Russian].

Malikov D.G. 2018. [Saiga antelope Saiga tatarica L., 1766 distribution in Minusinsk Depression during Late Neopleistocene] // Byulleten Moskovskogo Obshchestva Ispytatelei Prirody. Seriya Geologicheskaya. Vol.93. No.2. P.34-41 [in Russian].

Malikov D.G. \& Ovchinnikov I.Yu. 2019. [New data on the mammoth Mammuthus primigenius Blumenbach, 1799 distribution in the Minusinsk depression in Late Neopleistocene // [Materialy dokladov nauchnoi konferentsii "Geokhronologiya chetvertichnogo perioda: instrumental'nye metody datirovaniya noveishikh otlozheniy"]. Moscow. P.60 [in Russian].

Markova A.K., Puzachenko A.Yu., Kolfschoten T.V., Kosintsev P.A., Kuznetsova T.V., Tikhonov A.N., Bachura O.P., Ponomarev D.V., Plicht J. van der \& Kuitems M. 2015. Changes in the Eurasian distribution of the musk ox (Ovibos moschatus) and the extinct bison (Bison priscus) during the last $50 \mathrm{ka} \mathrm{BP} / /$ Quaternary International. Vol.378. P.99-110

Michelsen A., Quarmby C., Sleep D. \& Jonasson S. 1998. Vascular plant $15 \mathrm{~N}$ natural abundance in health and forest tundra ecosystems in closely correlated with presence and type of mycorrhizal fungi in roots // Oecologia. Vol.115. P.406-418.

Mistryukov A.A. 1991. [Geomorphological zoning of Nazarovsk-Minusinsk Intermountainous Depression]. Novosibirsk: OIGGM SO AN SSSR. 130 p. [in Russian].

Motuzko A.N., Vasiliev S.Yu., Vashkov A.A., Elenskiy Yu.N., Kravchenko E.N. \& Oreshnikov I.A. 2010. The mammoth and mammoth fauna of late Pleistocene from northern areas of the Minusinskaya hollow // Lazarev P.A. et al. (eds.). Proceedings of the VI International Mammoth Conference. Yakutsk. P.139-149.

Ovodov N.D. 2009. [Ancient animals of Khakassia] // Larichev V.E. (ed.). [Astroarheologii - natural science instrument of knowledge and protoscience astral religions priests of ancient cultures of Khakassia]. Krasnoyarsk: Gorod. P.189-199 [in Russian].

Petrova E.A. 2009. [The Formation History of the Large Mammals Fauna in Volga-Kama Region in the Middle and
Late Pleistocene] // PhD Dissertation in Zoology. Saint Petersburg: Zoological Institute RAS. 301 p. [in Russian]. Raghavan M., Themudo G.E., Smith C.I., Zazula G. \& Campson P.F. 2014. Musk ox (Ovibos moschatus) of the mammoth steppe: tracing palaeodietary and palaeoenvironmental changes over the last 50,000 years using carbon and nitrogen isotopic analysis // Quaternary Science Reviews. Vol.102. P.192-201.

Shpansky A.V. 2000. [Catalogue of the Collection of Quaternary Mammals of Tomsk Regional Museum of Local Lore]. Tomsk: Tomsk State University. 101 p. [in Russian].

Shpansky A.V. 2018. [Quaternary large mammals of the West Siberian Plain: habitat conditions and stratigraphic significance] // Dr. Sci. Dissertation in Geology. Tomsk: Tomsk State University. 313 p. [in Russian].

Stefaniak K., Lipecki G., NadachowskiA., SembaA., Ratajczak U., Kotowski A., Robličková M., Wojtal P., Shpansky A.V., Malikov D.G., Krakhmalnaya T.V., Kovalchuk O.M., Boeskorov G.G., Nikolskiy P.A., Baryshnikov G.F., Ridush B., Jakubowski G., Pawłowska K., Cyrek K., Sudoł M., Czyżewski Ł., Krajcarz M.T., Krajcarz M.T., Żeromska A., Gagat P., Mackiewicz P. 2019. Diversity of muskox Ovibos moschatus (Zimmerman, 1780) (Bovidae, Mammalia) in time and space based on cranial morphometry // Historical Biology. https:// doi.org/10.1080/08912963.2019.1666374

Tikhonov A.N. 1994. [Pleistocene musk ox (Ovibos pallantis) of the Urals and Western Siberia] // Trudy Zoologicheskogo Instituta RAN. Vol.256. P.92-110 [in Russian, with English summary].

van der Merwe N.J. \& Medina E. 1991. The canopy effect, carbon isotope ratios and foodwebs in Amazonia // Journal of Archaeological Science. Vol.18. P.249-259.

Vasiliev S.K., Parkhomchuk E.V., Serednev M.A., Milyutin K.I., Kuzmin Y.V., Kalinkin P.N. \& Rastigeev S.A. 2018. [Radiocarbon dating of rare Pleistocene megafauna species remains of Southern Siberia] // [Problems of Archaeology, Ethnography, Anthropology of Siberia and Neighboring Territories]. Vol.24. P.42-46 [in Russian].

Velichko A.A., Timireva S.N., Kremenetsky K.V., MacDonald G. \& Smith L. 2007. [West-Siberian Plain in the image of Late Glacial desert] // Izvestiya RAN. Seriya Geograficheskaya. Vol.4. P.16-28 [in Russian, with English summary].

Vislobokova I.A. 2008. The major stages in the evolution of artiodactyl communities from the Pliocene-early Middle Pleistocene of northern Eurasia: Part $1 / /$ Paleontological Journal. Vol.42. No.3. P.297-312.

Volkova V.S. \& Babushkin A.E. (eds.). 2000. [The Unified Regional Stratigraphic Scheme of the Quaternary Deposits of the West Siberian Plain]. Novosibirsk: Siberian Research Institute of Geology, Geophysics and Mineral Resources. 64 p. [in Russian].

Wooller M.J., Zazula G.D., Edwards M., Froese D.G., Boone R.D., Parker C. \& Bennett B. 2007. Stable carbon isotope compositions of eastern Beringian grasses and sedges: investigating their potential as paleoenvironmental indicators // Arctic, Antarctic and Alpine Research. Vol.39. P.318-331.

Zinova R.A. 1972. [Eopleistocene of North Central Kazakhstan and the Lower Boundary of Anthropogene] // Abstract of PhD Dissertation. Moscow: Geological Institute USSR Academy of Sciences. 26 p. [in Russian]. 